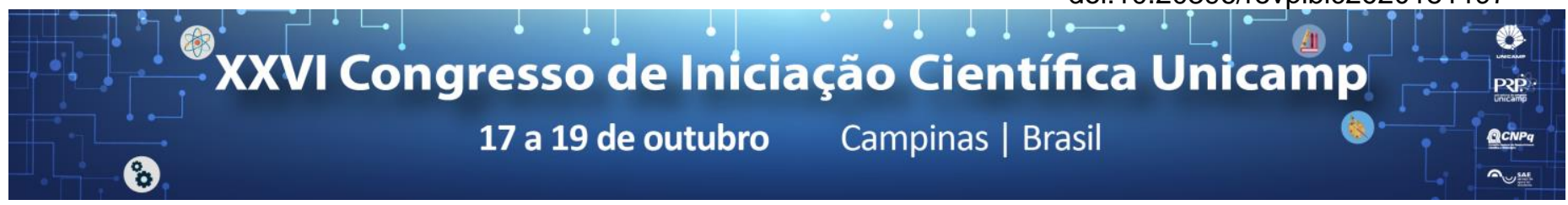

\title{
Caracterização de argamassas de revestimento com agregado reciclado (cinza)
}

\author{
Rebeca Mochnacs Pinto*, Patricia Stella Pucharelli Fontanini
}

\begin{abstract}
Resumo
O presente projeto tem como objetivo atingir novos resultados em relação ao uso de agregado miúdo reciclado cinza (proveniente da britagem de resíduos de concreto e argamassa) em argamassas de revestimento, definindo para estas limites de substituição do agregado miúdo natural pelo reciclado, de maneira que as propriedades da argamassa de revestimento não sejam afetadas. Desta forma, inicialmente foram avaliadas, considerando as normas técnicas vigentes, as propriedades do agregado miúdo reciclado, o qual foi obtido na usina de reciclagem de Campinas. Posteriormente, no Laboratório de Materiais da FEC - UNICAMP, produziu-se as argamassas mistas de revestimento, nas proporções usuais 1:1:6 e 1:2:9, com as quantidades de agregado miúdo reciclado nas proporções de $15 \%, 20 \%$ e $25 \%$ (em massa), as quais tiveram suas características físicas e mecânicas determinadas, verificando o atendimento a NBR 13281:2005 - Argamassa para Assentamento e Revestimento de Paredes e Tetos - Requisitos.
\end{abstract}

\section{Palavras-chave: \\ Agregado reciclado, Argamassa de revestimento, $R C C$}

\section{Introdução}

Com o aumento populacional das últimas décadas e o consequente crescimento das cidades, as atividades no setor da construção civil se intensificaram ainda mais. Como resultado, cerca de $50 \%$ do volume total de Resíduos Sólidos Urbanos produzidos no Brasil é composto pelos Resíduos da Construção Civil (RCC), os quais necessitam ser reciclados, evitando seu descarte irregular, o que agrediria em demasia o meio ambiente.

Assim, após seu processamento e reciclagem, estes são empregados, principalmente, como agregados miúdos reciclados, tornando-se componentes de argamassas de revestimento. Para tanto, o material selecionado necessita possuir caraterísticas físicas e mecânicas que possibilitem desempenho suficiente quando empregados neste tipo de argamassa, e assim, neste estudo faz-se uso das normas técnicas vigentes para agregados miúdos e argamassas, com o intuito de verificar se tais características estão sendo atendidas.

\section{Resultados e Discussão}

Após a coleta do agregado miúdo reciclado cinza, em laboratório deu-se início aos ensaios que permitiriam caracterizar o agregado. Foi determinada sua granulometria, obtendo-se uma dimensão máxima característica do agregado de $4,75 \mathrm{~mm}$ e um módulo de finura de 3,6. Para o teor de finos obteve-se $47,00 \%$, para a massa específica $2,283 \mathrm{~g} / \mathrm{cm}^{3}$ e para a absorção de água $0,46 \%$, o que comparados com resultados verificados em outras literaturas se demonstraram toleráveis de serem obtidos para um agregado reciclado, considerando sua procedência.

Posteriormente, produziu-se as argamassas mistas de revestimento, nos traços 1:1:6 e 1:2:9, sendo o agregado natural substituído pelo reciclado nas proporções em massa de $15 \%$, $20 \%$ e $25 \%$. Elaborou-se também argamassas que utilizavam apenas o agregado natural como o agregado miúdo componente, servindo estas de referência ao se comparar seus resultados obtidos nos ensaios exigidos na NBR 13281:2005, com os resultados obtidos para as argamassas com agregado reciclado.

Buscando tornar os resultados ainda mais confiáveis e, assim, com uma menor variabilidade, nesta pesquisa, para cada argamassa elaborada, foram moldados 16 corpos de prova de $5 \times 10 \mathrm{~cm}$, permitindo haver uma maior quantidade de amostras a serem analisadas.

Entre os ensaios realizados para as argamassas endurecidas, destacou-se o de resistência à compressão, o que se demonstrou bastante importante pois serve como um dos embasamentos para averiguar se uma argamassa de revestimento resistirá ou não às solicitações impostas quando aplicada em obra. Como resultado, obteve-se para o traço 1:1:6 referência, 15\%, $20 \%$ e $25 \%$, respectivamente, 13,2; 12,2; 12,7 e 12,8 MPa. Já para o traço 1:2:9 obteve-se 6,8;7,3; 6,3 e 6,9 $\mathrm{MPa}$, valores estes com um desvio considerado baixo se comparados à argamassa de referência e dentro dos limites exigidos na NBR 13281:2005, demonstrando-se, portanto, como um dos exemplos de viabilidade da substituição do agregado natural pelo reciclado.

\section{Conclusões}

Conforme a análise dos resultados permitiu-se constatar que tanto o agregado miúdo reciclado cinza, quanto as argamassas com este produzida, nos dois traços e nas três proporções em massa consideradas, resultaram num desempenho satisfatório em relação à referência.

Portanto, a substituição do agregado natural pelo reciclado nas argamassas de revestimento demonstra-se viável nas proporções aqui estudadas, e deve ser incentivada, uma vez que possibilita baratear os custos da construção civil ao reduzir o extrativismo de areia natural, além de diminuir o descarte irregular dos RCC, minimizando a agressão ao meio ambiente.

\section{Agradecimentos}

Agradeço ao PIBIC/CNPq, o qual financiou este projeto, a Profa. Dra. Patricia Stella Pucharelli Fontanini, pela sua orientação e a todos que me auxiliaram nesta pesquisa.

CALCADO, G. C. S. Influência da adição de agregados reciclados de resíduos de construção e demolição no desempenho de argamassas de cimento Portland. Rio de Janeiro, 2015, 101p.

PISSOLATO JUNIOR, O. Argamassa de revestimento utilizando areia proveniente da britagem de resíduo de construção civil. Campinas, 2016, $91 \mathrm{p}$. 